\title{
Germany to launch new gene programme ...
}

Munich. Germany is at last to become a full participant in international efforts to decipher the human genome, having been held back for years by social opposition to genetics research rooted in the nation's experience during the Nazi era.

Later this month, the research minister, Jürgen Rüttgers, is due to announce details of a new genetics research programme, costing DM50 million (US\$72 million) a year for eight years. The programme will give priority to human genetic diseases, and will be geared towards developing diagnostics and therapeutics.

Human genetics has not been completely ignored in Germany. But, unlike countries such as the United States, France and Britain, such research has been carried out by isolated groups without central organization or the strong support of government funding agencies. The new programme will now place German efforts on the same level as those of its partners.

According to Frank Laplace, who is responsible for the programme within the ministry of education and research (BMBF), one important goal will be to set up a resource centre to provide genetic probes for researchers and an extensive gene database. This will be based on the work of Hans Lehrach, a new director at the Max Planck Institute for Molecular Genetics in Berlin, who helped to develop the proposed programme.

Lehrach's group has been building a gene and clone database and an interactive service that provides scientists with probe filters for gene localization and clone identification. Clones, therefore, can be standardized between laboratories, which means "it is [a] much more efficient system for identifying large numbers of clones than sequencing," says Lehrach.

The programme will also provide competitive grant money whose extent and detailed priorities will be discussed at a meeting of the programme's international science advisory committee this week.

\section{China aims to treble research funding}

London. The Chinese government last week announced plans to treble investment in scientific research. But a rhetoric-weary science community may be in little rush to celebrate, as an apparent decision to increase funding on research and development from 0.5 per cent to 1.5 per cent of its gross domestic product was not accompanied by a detailed timetable.

The decision was announced at a meeting of China's ruling State Council, which announced that the target figure would be reached "by the year 2000 ".
The prospect of a German genome programme has been widely welcomed, both nationally and internationally. Bertrand Jordan, for example, of the Centre d'Immunologie de Marseille Luminy in France, a member of the programme's international scientific advisory board, says he is pleased that active opposition to genetics research in Germany has declined.

Jordan also claims Germany's late start has some advantages. German researchers "can assess the situation, and are not tied to existing projects," he says. "This should allow them to move forward more quickly."

This opinion is not universally shared. Sir Walter Bodmer, director general of the Imperial Cancer Research Fund in the United Kingdom, and a former president of the Human Genome Organization (HUGO) in

\section{... as France risks being left behind}

London \& Paris. One of the first decisions facing the government of France's new president, Jacques Chirac, due to be announced this week, will be its response to recent initiatives in the United States and the United Kingdom to start sequencing the entire human genome (see Nature, 375,$93 ; 1995$ ).

France has become a major player in both gene mapping and gene sequencing, in particular, through the work of the Paris-based Centre d'Etudes du Polymorphisme Humain (CEPH) and the Généthon laboratory, and with a substantial input in funds from the French Muscular Dystrophy Association (AFM). But many observers feel that it, nonetheless, lacks a coherent national strategy, or even a consensus on how to move forward.

Fears that France could be left behind if the joint proposal by US and UK groups is adopted are reflected in a recent report commissioned by the AFM. This report claims that such a project involves not just scientific and medical interests, but also considerable financial and industrial stakes - pointing out, for example, that the rights to a gene associated with obesity were recently sold for $\mathbf{\$ 2 0}$ million.

It warns that the launching of an American programme - either unilaterally or bilaterally with the Sanger Centre (see Nature 375,$93 ; 1995$ ) — would place France in a "position of dependence" and risk giving US companies a competitive advantage. Such dependence, it suggests, could restrict French scientists from getting access to data.

The report also warns that tying into an international programme could potentially create conflict with France's own research priorities, while French research agencies
Europe, says that starting late "means time lost with training and becoming involved". But he still welcomes Germany's commitment to human genome research. "It will add strength to what is being done in Europe", he says.

Daniel Cohen, director of the Centre D'Etude du Polymorphisme Humain $(\mathrm{CEPH})$ in Paris, says that the new programme means that Germany has "finally stopped using history as a pretext not to do research in genetics", and that he expects German involvement to lead to improved sequencing and other technology.

"There have been no new developments in the last ten years," says Cohen. "The Germans are good at organization on a large scale, and they do very good research."

Toni Feder

are concerned that the big money needed for 'megasequencing' would reduce their budgets for other priority topics.

One possibility, suggests the AFM report, is that France might launch an independent effort to sequence the entire genome in parallel with any US/UK effort. But given the costs involved, others see greater possibilities in international collaboration, and say that they are keen to contribute to the type of project being outlined by British and US research groups.

Whatever happens, everybody agrees that the government needs to decide, and soon, how much public money to make available. "The French should be active in this project," says Daniel Cohen, the head of CEPH, adding that "certainly there is a danger that France could be left behind."

Bernard Barateau, president of AFM, describes it as "astonishing" that the recent presidential campaign apparently ignored "one of the most massive scientific medical and industrial revolutions" of the end of the century. "It proves that the politicians aren't up to date, but it's not too late to catch up," he says, adding that France needs a strong domestic programme if it is to be a credible partner in any international effort.

But although Barateau's warning that France risks being left behind may appeal to the chauvinistic instincts of the new Gaullist government, the possibilities for action may be hindered by the confusion that now reigns in French genetics.

The previous government stripped the national genome agency of its powers and resources, while the money needed for AFM to repeat Généthon's mapping achievements is this time out of its reach. David Dickson \& Declan Butler 